\title{
SATE MARANGGIs KULINER KHAS KABUPATEN PURWAKARTA
}

\section{MARANGGI SATE: A CULINARY FROM PURWAKARTA REGENCY}

\author{
Irvan Setiawan \\ Balai Pelestarian Nilai Budaya (BPNB) Jawa Barat \\ Jl. Cinambo no. 136 Ujungberung - Bandung 40294 \\ e-mail: kamaliasetiawan@yahoo.co.id
}

\begin{abstract}
Abstrak
Istilah khas pada sate maranggi adalah cara halus untuk menyembunyikan kata tradisional yang terkadang dimaknai secara sensitif oleh sebagian kalangan khususnya pada jenis kuliner tradisional. Strategi ini tidak lain diarahkan pada upaya mengundang daya tarik wisatawan lokal dan mancanegara untuk datang dan menikmati sate maranggi di Kabupaten Purwakarta. Penelitian yang menggunakan metode deskriptif kualitatif ini bertujuan untuk mengangkat salah satu kuliner tradisional Kabupaten Purwakarta dengan menitikberatkan pada sisi sejarah berikut asal mula penamaan sate maranggi, proses pembuatan dan upaya pelestarian yang dilakukan oleh Pemerintah Daerah Kabupaten Purwakarta. Diperoleh data di lokasi penelitian sebuah hasil yang cukup positif dari upaya pemberdayaan yang dilakukan oleh Pemerintah Daerah Kaupaten Purwakarta sehingga nama sate maranggi sudah bergaung dari tingkat nasional hingga ke mancanegara. Upaya kreatif baik dari segi variasi rasa, pola sajian, dan promosi yang gencar terbukti ampuh untuk mengangkat salah satu warisan budaya tak benda yang ada di Kabupaten Purwakarta.
\end{abstract}

Kata kunci: Sate maranggi, kuliner, khas, Purwakarta.

\begin{abstract}
Typical term on sate Maranggi is a subtle way to hide the traditional word that is sometimes interpreted sensitively by some circles, especially on traditional culinary type. This strategy is directed to invite the attraction of local and foreign tourists to come and enjoy sate Maranggi in Purwakarta Regency. The research uses qualitative descriptive method which is aimed to lift one of traditional culinary in Purwakarta District with emphasizing on the history of naming sate Maranggi, the process of making it and conservation efforts conducted by the Regional Government of Purwakarta Regency. The data obtained in the research location showed a positive result of the empowerment efforts undertaken by the Regional Government of the District of Purwakarta. Hence the name of sate Maranggi has well-known both national and international. Creative efforts both in terms of taste variations, dish patterns, and promotions are vigorous proven to lift one of the cultural heritage in Purwakarta District.
\end{abstract}

Keywords: Sate Maranggi, Culinary, Typical, Purwakarta.

\section{A. PENDAHULUAN}

Makanan dan minuman merupakan kebutuhan pokok manusia yang harus dipenuhi. Cita rasa yang terkandung dalam setiap menu makanan dan minuman adalah kelanjutan dari telah dipenuhinya terlebih dahulu kebutuhan pokok tersebut. Perihal cita rasa berikut variasi dari cara penyajian dan proses pemasakan adalah hal yang sebenarnya sudah lama ada dan masih di anggap unsur nomor dua karena memang kurang menjadi syarat utama dari sebuah pemenuhan kebutuhan pokok pada masa dahulu.

Beranjak dari zaman ke zaman, cita rasa makanan dan minuman menjadi 
semakin mengarah pada unsur utama dalam setiap sajian. Kondisi ini memungkinkan adanya unsur baru dari cita rasa yang akan menggerus cita rasa lama yang sudah lama ada. Meskipun sebenarnya cita rasa "lama" tersebut sebenarnya terasa nikmat, namun apa yang menjadi unsur baru dan trend memang menjadi daya tarik tersendiri dari sekelompok masyarakat untuk mencoba dan menjadikannya sebagai sebuah prestise. Sebagai contoh adalah maraknya instant food, atau dapat dikatakan junk food, yang saat ini sudah tersebar di setiap penjuru wilayah di tanah air. Sangat ironis memang karena sebuah sajian yang didesain dan diracik oleh nenek moyang bangsa kita dan menjadi trade mark dari sebuah wilayah kemudian secara tiba-tiba harus terusir oleh sajian baru yang datang begitu cepat. Padahal menurut Wurianto (2008: 3) bahwa identifikasi dan klarifikasi kuliner tradisional dapat diketahui dari salah satu jenis makanan, minuman, dan jajanan.

Sajian baru yang dimaksud dapat berupa makanan ringan (snack), jajanan (fast food), maupun makanan berat. Dan, begitu juga beberapa makanan ringan yang saat ini sudah marak dan mudah diperoleh mulai dari supermarket maupun warungwarung kecil. Berbeda halnya dengan dua jenis makanan di atas, untuk jenis makanan berat pada saat ini, kuliner khas atau tradisional masih dapat bersaing dengan jenis-jenis makanan berat dari luar. Hal ini dapat dilihat dari persaingan antara Waralaba Fried Chicken dengan berbagai kedai atau restorant yang banyak menyajikan kuliner khas nusantara. Agar lebih menarik konsumen, beberapa daya tarik yang disediakan untuk menyaingi makanan luar dapat berupa nama yang khas atau aneh, kolaborasi makanan tradisional dengan sajian lainnya, maupun arsitektur rumah makan itu sendiri yang diupayakan unik dan mampu memikat mata.

Meskipun sudah banyak upaya yang dituangkan untuk menarik konsumen, sebagai generasi pewaris cita rasa nenek moyang sudah seharusnya kita harus tetap berupaya untuk melestarikan cita rasa yang terkandung dalam berbagai jenis kuliner agar tidak punah.

Indonesia memiliki beragam keunikan baik dari segi cita rasa, penyajian, maupun cara pembuatan yang terkandung dalam berbagai menu makanan khas mulai dari tingkat desa, kecamatan, kabupaten/kota, hingga ke tingkat provinsi. Salah satu kabupaten yang memiliki kuliner khas yang sudah terkenal hingga ke tingkat provinsi yaitu Purwakarta yang terkenal dengan sate maranggi. Ketenaran sate maranggi di Kabupaten Purwakarta sudah tahun 1960-an. Dimulai dari dua sentra sate maranggi, yaitu daerah di sekitar stasiun Plered dan Hutan jati Cibungur, kekhasan cita rasa sate maranggi tersebut kemudian semakin dikenal dan hingga kini dapat dengan mudah ditemukan utamanya di seantero wilayah Kabupaten Purwakarta.

Beberapa hal yang menyangkut kekhasan sate maranggi di Kabupaten Purwakata meliputi: asal usul Sate Maranggi; persiapan, pelaksanaan, dan cara penyajian sate maranggi; dan proses pewarisan kuliner khas sate maranggi?

Beberapa definisi yang menjadi kerangka berfikir tulisan tentang sate maranggi meliputi: sate maranggi, bahan dasar, bahan pendukung, bumbu, proses pemasakan, dan cara penyajian. Sate Menurut Kamus Bahasa Indonesia (Tim Penyusun Kamus Pusat Bahasa, 2008:

1272), sate berasal dari kata "satai", yaitu irisan daging kecil-kecil yg ditusuk dan dipanggang, diberi bumbu kacang atau kecap: -- ayam; -- kambing. Variasi sajian sate di Indonesia sangat beragam baik dari segi cita rasa, maupun dari cara penyajiannya.

Sate Maranggi adalah salah satu jenis kuliner khas Kabupaten Purwakarta yang dibuat dari potongan berbentuk dadu berukuran sekitar $1 \mathrm{~cm} .4$ potongan daging tersebut disatukan sejajar dengan cara ditusukan pada bilah bambu runcing 
berukuran sekitar $20 \mathrm{~cm}$. yang kemudian diberi bumbu lalu dipanggang hingga matang. Bahan dasar adalah bahan makanan (mentah) utama yang digunakan untuk membuat sebuah menu masakan. Jumlah bahan dasar tergantung dari menu masakan itu sendiri. Sate misalnya, bahan utamanya hanya berupa daging mentah. Adapun daging mentah tersebut dapat berasal dari daging ayam, kambing, sapi, dan lain-lain. Bahan pendukung adalah peralatan yang digunakan untuk memasak sebuah makanan. Variasi dari peralatan yang dibutuhkan untuk membuat sebuah menu tergantung dari cara dan proses pemasakannya. Sate misalnya, hanya membutuhkan peralatan yang terdiri dari tusuk bambu, arang, kipas, pisau, dan pemanggang. Bumbu dapat disamakan dengan rempah-rempah yang diperlukan untuk memperoleh cita rasa yang diinginkan dari sebuah menu makanan. Cita rasa yang dimaksud dilihat dari rasa khas pada sebuah atau suku bangsa. Sebagai gambaran, berdasarkan pengalaman penulis di tiga suku bangsa (Minang, Aceh, Sunda), Suku bangsa Minang kerap memasak dengan cita rasa gurih dan pedas, masakan Aceh lebih dominan menggunakan selera gurih asam dan pedas, sementara masyarakat Sunda menyukai rasa gurih, asin manis, dan pedas. Proses pemasakan adalah upaya agar bahan makanan berikut bumbu yang telah diolah menjadi matang dan siap saji.

Definisi matang tergantung dari proses pemasakan yang dapat dilakukan dengan cara direbus, dimasak dengan batu panas, dikukus, dipanggang, digoreng, difermentasi, diawetkan, dimasak di atas api (Tim Teknis Direktorat Jenderal Kebudayaan, 117 - 118).

Cara penyajian makanan dapat dilakukan sesuai keperluan, ada yang disajikan untuk konsumsi harian, acara bersifat keluarga, kepentingan komersil, dan lain-lain.

Patut diperhatikan bahwa jumlah menu tergantung dari cara penyajiannya. Ada cara penyajian yang hanya membutuhkan satu menu saja, ada juga yang membutuhkan beberapa menu. Keterkaitan dengan tradisi sangat kental dalam proses penyajian makanan. Makanan dalam sebuah tradisi terbagi dalam makanan ritual, konsumsi atau sesajen, dan keseluruhannya mendapat posisi yang cukup penting sehingga perlakuan khusus kerap diterapkan mulai dari proses pemasakan hingga cara penyajiannya.

Tulisan tentang sate maranggi ini dimaksudkan mendeskripsikan kuliner Sate Maranggi mulai dari proses pemasakan hingga cara penyajian. Tujuannya adalah untuk menjadi salah satu referensi kajian yang diharapkan dapat menjadi salah satu bahan dalam proses pengajuan penetapan sebagai salah satu warisan budaya tak benda Indonesia.

Lokasi kajian adalah seperti yang tertuang dalam judul di atas, yaitu di Kabupaten Purwakarta, khususnya di sentra-sentra kuliner sate maranggi, di antaranya Kecamatan Pondok Salam, Kecamatan Pasawahan, Kecamatan Cibungur, dan Kecamatan Plered.

\section{B. METODE PENELITIAN}

Penelitian mengenai kuliner sate maraggi merupakan sebuah penelitian yang bersifat deskriptif kualitatif. Artinya bahwa bahasan yang disajikan termuat dalam bentuk deskripsi tanpa menguak sisi statistik baik dalam bentuk tabel ataupun cross tabulasi.

Sajian data yang ada bersumber dari data primer dan sekunder. Data primer diperoleh dari keterangan informan yang diperoleh dengan menggunakan teknik snowball sampling. Dengan kata lain, informan awal akan memberikan informasi identitas informan lainnya yang tahu dan mengerti seluk beluk keberadaan sate maranggi di Kabupaten Purwakarta. Sumber pertanyaan yang akan ditanyakan pada informan biasanya telah tersaji dalam sebuah pedoman wawancara. Hasil wawancara tercatat baik dalam bentuk tulisan kunci ataupun terekam dalam 
format audio. Sementara itu, data sekunder diperoleh dengan mengunjungi sumber informasi ilmiah yang biasanya ada di perpustakaan. Perlu diketahui bahwa tulisan yang mengkaji mengenai sejarah dan deskripsi sate maranggi secara kualitatif saat ini masih sangat minim dan tersaji secara parsial.

\section{HASIL DAN BAHASAN \\ 1. Sejarah Sate Maranggi}

Sedikit bukti sejarah yang dapat dikemukakan mengenal asal mula sate maranggi. Namun, ada beberapa versi di dalamnya karena sumber sejarah tertulis belum/tidak dapat ditemukan hingga kini. Oleh karena itu, versi yang ada bersumber dari informan, dan pakar kuliner yang meneliti kesamaan bahan dan proses pemasakan antara sate maranggi dengan kuliner sejenis lainnya.

Hal pertama yang akan dijelaskan di sini adalah penamaan sate maranggi. Kenapa disebut dengan nama "Maranggi"? Informasi yang dberikan oleh informan mengerucut pada penjual sate maranggi di Plered. Kata "Maranggi" dalam Sate Maranggi merupakan sebuah nama panggilan yang ditujukan pada seorang penjual Sate Maranggi, yaitu Mak Anggi. dari Jawa Tengah. Sekitar tahun 1960-an, ia berjualan sate dengan menggunakan tenda di daerah tempat tinggalnya, yakni daerah Cianting. Beliau menjajakan sate yang sudah cukup dikenal di daerah tersebut.

Masyarakat atau penyuka sate, pada waktu itu, apabila hendak merasakan sate tersebut akan mengatakan hendak ke sate Mak Anggi. Keseringan menyebutkan nama tersebut membuat sate tersebut dinamakan Sate Maranggi. Tambahan huruf "R" dalam "MaRanggi" digunakan untuk mempermudah pengucapan dalam memberikan nama kuliner tradisional tersebut.

Tidak diketahui secara pasti tanggal berapa nama kuliner Sate Maranggi mulai tenar. Data yang diperoleh dari informan menyebutkan bahwa seorang penjual Sate
Maranggi bernama Bustomi Sukmawirdja atau dikenal dengan sebutan Mang Udeng, telah berjualan Sate Maranggi pada tahun 1962 di Kecamatan Plered. Informasi tersebut sekaligus mematahkan permasalahan lokasi asal mula Sate Maranggi yang sebelumnya juga diklaim oleh Kecamatan Wanayasa. Adapun angka tahun awal adanya Sate Maranggi di Wanayasa adalah lebih muda dibandingkan dengan angka tahun informasi keberadaan Sate Maranggi di Plered, yaitu tahun 1970, atau lebih muda 8 tahun. Informasi atau data awal mula adanya penjual Sate di Wanayasa datang dari seorang dengan nama panggilan Mak Unah. Beliau menyebutkan bahwa sekitar tahun 1970 beliau telah berjualan sate. Tidak lantas beliau mengistilahkan dengan nama Sate Maranggi. Beliau hanya menyebutkan Sate Panggang. Dan, beliau juga telah mengetahui bahwa di Plered sebelumnya juga telah ada yang berjualan sate, yaitu Mang Udeng. Daging yang digunakan kala itu berasal dari daging sapi atau kerbau. Mak Unah melanjutkan bahwa, ia memang sebelumnya juga menggunakan bahan daging yang sama (sapi dan kerbau). Sekitar tahun 1965, beliau mencoba menggunakan jenis daging lain dalam racikan bumbunya, yaitu daging domba. Menurut beliau bahwa racikan bumbunya yang dimasak dengan menggunakan daging domba lebih enak jika dibandingkan dengan menggunakan jenis daging yang lain.

Mengkaji dari data sejarah tersebut di atas, antara Wanayasa dan Plered terdapat sebuah sinergi yang mencuatkan nama Maranggi sebuah sebuah kuliner yang kemudian mengemuka dan menjadi ikon Kabupaten Purwakarta. Memang dalam melihat angka tahun, Wanayasa lebih muda dibandingkan dengan Plered. Namun dilihat dari jenis daging yang digunakan membuat kedua daerah tersebut dapat dikatakan sebagai awal mula adanya Sate Maranggi di Kabupaten Purwakarta. Wanayasa merupakan "pencipta" dari Sate Maranggi dengan menggunakan bahan 
dasar daging domba, sedangkan Plered merupakan "pencipta" Sate Maranggi" dengan menggunakan bahan dasar daging sapi dan kerbau.

Perihal adanya menu daging domba yang belakangan menjadi salah satu menu baru di samping menu terdahulu, yaitu daging kerbau atau sapi diyakini merupakan salah satu perubahan yang cukup signifikan terjadi apabila dilihat dari pola kehidupan masyarakat pada waktu itu. Pemilihan daging kerbau atau sapi sebagai bahan utama pembuatan sate maranggi sekiranya dapat menggambarkan mengenai kehidupan masyarakat pada waktu itu yang sebagian besar bekerja sebagai petani. Sapi atau kerbau menjadi hewan andalan yang multiguna karena dapat difungsikan untuk membantu membajak sawah, menarik beban berat ataupun dapat difungsikan sebagai tenaga angkutan umum berbentuk gerobak. Oleh karena itu, daging yang biasa dikonsumsi masyarakat pada waktu itu, selain unggas (ayam, bebek) dan ikan, adalah daging kerbau atau sapi . Sehingga wajar apabila bahan daging yang digunakan untuk membuat sate maranggi adalah daging kerbau atau sapi .

Domba yang menjadi bahan pengganti atau varian baru sate maranggi yang muncul kemudian, apabila dilihat dari segi fungsinya banyak mengarah pada fungsi ekonomi. Jangka waktu beranak pinak dan pertumbuhan yang lebih cepat dari pada sapi atau kerbau menjadi satu pilihan favorit bagi peternak untuk memilih domba. Pada kondisi kekinian, selain sebagai salah satu hewan kurban, kulit domba juga memiliki nilai jual cukup tinggi yang digunakan sebagai salah satu bahan industri kreatif.

Perihal bumbu yang digunakan untuk membuat Sate Maranggi di kedua daerah tersebut pada dasarnya adalah sama. Yang menjadi permasalahan adalah ide siapa sehinga terciptalah sebuah racikan khas bumbu Sate Maranggi. Informasi tersebut di atas hanyalah menyebutkan bahwa yang dikatakan sebagai Sate Maranggi telah ada sejak tahun 1962 di Plered tanpa memperinci bahan dan proses pembuatannya.

Seorang juru masak yang cukup terkanal bernama Haryo Pramoe, mengatakan bahwa Sate Maranggi merupakan hasil asimilasi dengan budaya China. Hal tersebut dilatarbelakangi oleh adanya kesamaan bumbu dan sejarah kuliner di Indonesia. Sebagaimana diketahui bahwa Orang China telah datang dan menetap di Indonesia sejak lama. Mereka turut membawa kelengkapan budaya dan diimplementasikan ke dalam kultur Indonesia. Fakta sejarah kuliner seperti awal mula bakso, Mie Ayam, Siomay, dan lain-lain adalah jelas berasal dari masyarakat China di Indonesia. Hal ihwal Sate Maranggi juga demikian halnya. Walaupun ada perubahan dalam media bahan, yaitu daging, cara penyajian dengan menggunakan metode rendam dan siraman bumbu menurut Haryo Pramoe (dalam travel.kompas.com, 2016) berasal dari China. Dibuktikan bahwa bumbu rempah yang digunakan Sate Maranggi, menurut Haryo Pramoe, sama persis dengan dendeng babi dan dendeng ayam yang dijual di Hongkong, China, dan Taiwan. Masyarakat Indonesia, khususnya dua wilayah di Kabupaten Purwakarta (Wanayasa dan Plered) yang memiliki kultur Islam kemudian mengganti jenis daging tersebut dengan daging domba, sapi, dan kerbau untuk dipadukan dengan bumbu yang sama.

Terlepas dari penjelasan Chef Haryo Pramoe di atas, sebuah kuliner yang bernama Sate Maranggi adalah memang sebuah kuliner tradisional. Perihal kesamaan bumbu antara Sate Maranggi dengan bumbu yang telah dikatakan oleh Haryo Pramoe mungkin ada beberapa kesamaan namun dilihat dari cara pengolahan, proses pemasakan dan cara penyajian adalah jelas berbeda dengan kuliner yang dijelaskan oleh Haryo Pramoe. Secara keseluruhan, Sate Maranggi memang menarik baik dari rasa maupun cara penyajian sehingga wajar jika Sate Maranggi menjadi kuliner khas 
sekaligus menjadi ikon Kabupaten Purwakarta.

Pedagang sate maranggi biasanya dilakukan oleh laki-laki usia dewasa hingga tua. Ngider atau berkeliling adalah hal yang biasa dilakukan oleh penjual sate maranggi pada zaman dahulu untuk menjajakan dagangannya dengan berjalan kaki. Mempersiapkan bahan jualan dilakukan pada malam hari dan mulai berdagang mulai pagi hingga petang.

Seperangkat peralatan yang wajib dibawa adalah alat panggangan yang terdiri dari hihid ${ }^{1}$, wadah arang, dan arang itu sendiri. Selain itu, turut dibawa pula beberapa buah piring dan gelas serta satu ember kecil berisi air untuk membersihkan piring yang telah dipakai konsumen. Air minum - biasanya air teh tawar - yang dibawa dengan menggunakan teko alumunium juga disediakan. Dan, bahan utama yang dibawa bumbu kecap, satu set sate yang telah siap panggang, dan nasi yang dibungkus dengan daun pisang.

Bahan dagangan yang telah disiapkan ditaruh pada dua kotak besar untuk kemudian dipikul dengan menggunakan sebilah bambu. Kotak besar yang dimaksud berbentuk khas dan mencirikan bahwa itu adalah kotak untuk berdagang sate maranggi. Terbuat dari beberapa jenis bahan, yaitu rotan, kayu, dan papan. Kayu dan papan digunakan untuk membuat kotaknya, sedangkan rotan digunakan untuk pembuatan alat yang berfungsi sebagai pengait agar dapat dipikul.

Rute yang dilalui untuk berjualan sate maranggi biasanya tetap, dan akan berhenti pada satu lokasi yang biasa menjadi tempat konsumen biasa membeli sate maranggi. Apabila tidak ada yang membeli, selang beberapa saat, penjual sate maranggi akan berangkat menuju titik selanjutnya. Pola tersebut biasanya bertahan cukup lama dalam berjualan. Adapun titik pemberhentian penjual sate maranggi yang baru biasanya apabila ada

${ }^{1}$ Kipas tradisional masyarakat suku sunda keramaian, seperti pasar malam, panggung pertunjukan, dan lain-lain yang berbentuk kerumunan massa. Walaupun diperkirakan akan banyak pembeli, namun apabila lokasi kerumunan massa tersebut dirasa cukup jauh, penjual sate maranggi lebih memilih untuk tidak menuju pada titik tersebut. Hal tersebut disebabkan transportasi yang digunakan untuk mengangkut alat berjualan pada waktu itu sangat susah.

Saat ini, pola berjualan ngider 'berkeliling' sudah mulai langka. Walaupun sudah langka, kita masih dapat menjumpainya dan biasanya hanya ada di tempat-tempat hiburan, sarana rekreasi, dan taman. Salah satu tempat favorit bagi para "pengider" sate maranggi adalah di Situ Buleud yang terletak di tengah ibukota Kabupaten Purwakarta. Alun-alun Mesjid Agung Purwakarta juga menjadi salah satu tempat mangkal dari para penjual sate maranggi. Satu bentuk perubahan yang belum terlihat dari perubahan pola penjualan sate maranggi adalah cara ngider menggunakan sepeda motor yang saat ini sudah biasa dilakukan oleh penjual sate padang.

Sebagai ganti dari pola penjualan dengan cara ngider, bagi mereka yang memiliki modal lebih besar, kini lebih menyukai pola penjualan menetap. Warung atau kios kecil kini menjadi salah satu ciri dari penjual sate maranggi. Plered menjadi sentra terbesar dari penjual sate maranggi dengan pola mangkal atau menetap tersebut. Jalan utama memasuki wilayah Plered kini telah banyak berjejer warung-warung sate maranggi.

Meski sudah menggunakan pola menetap, namun kekhasan dari kotak yang biasa digunakan untuk ngider masih tetap digunakan terutama pada kios-kios kecil, meskipun ada perubahan pada diameter kotak jualan yang lebih besar. Hanya sekedar mencirikan sebuah kekhasan dan ciri bahwa warung atau kios tersebut menjual Sate Maranggi.

Bagi yang bermodal lebih besar, pola penjualan menetap khusus Sate 
Maranggi sudah tidak menggunakan atau memakai gerobak khas sate maranggi, namun sudah layaknya sebuah rumah makan biasa. Untuk mencirikan bahwa rumah makan tersebut menyediakan menu sate maranggi adalah dengan cara memajang daging kambing utuh di etalase yang menghadap ke jalan. Pola penjualan secara mangkal atau menetap berbentuk rumah makan telah menyebar di wilayah Wanayasa dan Cibungur.

\section{Komunitas Penjual Sate Maranggi}

Ketenaran kuliner bernama sate maranggi dimulai dari beberapa penjual sate maranggi yang berjualan di suatu tempat dan kemudian menyebar terutama di wilayah Kabupaten Purwakarta. Dari berita dan informasi yang disampaikan dari mulut ke mulut, sedikit demi sedikit, nama sate maranggi mulai dikenal oleh masyarakat tidak hanya masyarakat di Kabupaten Purwakarta saja tetapi juga beberapa wilayah yang berdekatan.

Kelompok penjual sate maranggi yang pada awalnya hanyalah sekumpulan penjual yang bebas bergabung tanpa ada ikatan tertentu saat ini sudah dibentuk menjadi sebuah komunitas yang berlokasi di sebelah Stasiun Plered. Sementara itu, kelompok penjual sate maranggi di wilayah lain di Kabupaten Purwakarta masih belum memiliki nama.

Kampoeng Maranggi, nama komunitas penjual sate maranggi yang baru diresmikan beberapa bulan yang lalu, tepatnya 6 April 2016. Tidak kurang dari 120 penjual sate maranggi yang menjadi anggota komunitas Kampoeng Maranggi yang berlokasi di sebelah stasiun Plered. Para penjual sate maranggi tersebut secara umum merasa sangat senang atas berdirinya Kampoeng Maranggi karena pembeli - dan mereka sendiri - tidak perlu bersusah payah untuk merasakan nikmatnya sate maranggi. Cukup datang ke Kampoeng Maranggi, semua varian sate maranggi telah tersedia.

Antisipasi dari membludaknya pembeli dari luar kota, ditambah dengan para penumpang yang turun dan naik di Stasiun Plered, pemerintah daerah telah menyediakan lahan parkir yang cukup luas. Sehinga para pembeli terutama tidak perlu berjalan kaki untuk datang dan menikmati sate maranggi.

Lokasi Kampoeng Maranggi yang sengaja didirikan di Plered disebabkan sejarah asal mula sate maranggi mengerucut ke daerah tersebut. Di samping itu, faktor penunjang yang dirasa sangat penting terhadap minat calon pembeli datang dan menikmati sate maranggi menurut Hardjasaputra (2004: 19) bahwa Plered sejak masa penjajahan sudah dikenal sebagai daerah pembuat genteng dan keramik hias, tepatnya Desa Anjun yang telah ada sejak dahulu. Hal ini tentunya menambah nilai jual keberadaa Kampoeng Maranggi. Dengan demikian, setelah atau sebelum menikmati sate maranggi, para pembeli juga dapat melihat-lihat berbagai macam keramik khas Desa Anjun yang juga dikatakan telah mendunia.

Fasilitas yang disediakan di Kampoeng Maranggi adalah berupa 2 unit bangunan permanen sejajar tanpa sekat Fasilitas penerangan berupa lampu listrik juga telah disediakan. Semenjak dibuka hingga saat ini (2017), para penjual sate maranggi yang menempati lapak-lapak di Kampoeng Maranggi tidak dikenakan biaya.

Fasilitas untuk berdagang adalah mutlak disediakan oleh para penjual Sate Maranggi sendiri. Sementara pihak pengelola hanya mengharuskan agar bentuk peralatan harus menggambarkan ketradisionalan seperti layaknya seorang penjual Sate Maranggi Keliling. Oleh karena itu, seluruh fasilitas berdagang Sate Maranggi berbentuk dua buah tanggungan 'pikulan' lengkap dengan peralatan pendukung untuk membuat Sate Maranggi.

Adapun biaya yang ada hanyalah berupa biaya kebersihan dan keamanan. Jam buka Kampoeng Maranggi adalah 24 jam. Namun, maksimal para penjual hanya kuat hingga pukul 03.00 WIB Dini hari. 
Berselang 2 sampai dengan 3 jam kemudian, beberapa penjual kembali berdagang. Hal ini disebabkan lokasi Kampoeng Maranggi yang berdekatan dengan stasiun kereta Plered. Para penumpang yang pulang dan berangkat di Stasiun Plered kerap menikmati atau membawa sate maranggi sebagai bekal mereka di perjalanan. Khusus bulan ramadhan atau bulan puasa, penjual Sate Maranggi mulai membuka lapaknya sekitar pukul 16.00 WIB sampai dengan pukul 03.00 WIB.

\section{Kekhasan dari Cara Pembuatan hingga Penyajian}

Pemilihan bahan, proses, dan cara penyajian kuliner sate maranggi tidak menggunakan unsur ritual tertentu. Hanya ada doa-doa dalam agama Islam saja yang menyertai dalam tahap awal hingga akhir pembuatan sate maranggi. Hal ini dapat dilihat dari kemunculan atau awal terlihatnya penjualan sate maranggi sekitar tahun 1962-an. Sebuah angka tahun yang tergolong baru untuk sebuah kuliner yang biasa dibuat sesajen, dan dalam tahap pembuatannya juga harus menggunakan upacara atau ritual tertentu. Berbeda halnya dengan nasi kuning ataupun bakakak hayam yang sudah ada jauh sebelum kemunculan sate maranggi.

Di Purwakarta, ada beberapa kawasan atau wilayah yang memiliki perbedaan dalam mengolah atau menyajikan sate maranggi. Beberapa wilayah dimaksud di antaranya wilayah Plered, Bojong, Wanayasa, dan Cibungur. Meskipun tidak begitu mencolok, perbedaan ini merupakan bagian dari pelestarian yang dituangkan dalam bentuk kreativitas untuk meningkatkan omzet penjualan sate maranggi. Dengan demikian, ada beberapa bagian dari prosedur pembuatan dan penyajian sate maranggi yang berbeda antara satu wilayah dengan wilayah lainnya dalam lingkup Kabupaten Purwakarta.

\section{a. Peralatan \\ - Peralatan Memanggang}

Secara garis besar sate merupakan sajian yang dihasilkan dari jenis pengolahan dengan cara dipanggang. Oleh karena itu, peralatan pokok yang dibutuhkan adalah tempat panggangan, arang, dan kipas (hihid ataupun kipas angin). Ukuran tempat panggangan bervariasi mulai dari yang terkecil sekitar $30-40 \mathrm{~cm}$ hingga yang terbesar mencapai 1,5 meter. Tingkatan ukuran alat panggangan tersebut didasarkan oleh omzet penjualan mulai dari skala kecil hingga skala besar. Ukuran terbesar dari hasil pengamatan yaitu di rumah makan sate maranggi milik $\mathrm{Hj}$. Yetty yang berukuran sekitar $1,5 \mathrm{~m}$. Ukuran terkecil biasa dipakai oleh para penjual sate maranggi keliling yaitu sekitar $30 \mathrm{~cm}$.

Kipas digunakan untuk membantu hembusan angin yang mempercepat proses pematangan sate maranggi. Dua jenis kipas yang digunakan untuk proses tersebut adalah kipas manual (tenaga manusia), dan kipas listrik. Kipas manual atau orang sunda biasa menyebut dengan istilah hihid merupakan sebuah peralatan tradisional yang terbuat dari bambu yang dianyam hingga membentuk sebuah lembaran berukuran $25-30 \mathrm{~cm}$. Lembaran dari hasil anyaman tersebut kemudian diberi gagang dan diikat. Proses untuk mengipasi sate maranggi dilakukan dengan mengayunkan kipas kekiri dan kekanan. Proses tersebut menghasilkan angin dari dua arah. Terkadang penjual sate membolakbalikkan sate untuk memastikan agar sate matang merata. Cara tersebut menghasilkan tingkat kematangan yang merata baik dari sisi kiri maupun kanan. Hanya saja proses yang menggunakan tenaga manusia sangat sulit untuk melakukan proses pematangan sate maranggi dalam jumlah yang cukup banyak. Kipas bertenaga listrik adalah jawabannya. Cara kerjanya cukup menyalakan kipas kemudian ia hanya bertugas membolak-balikkan sate agar pematangan merata. Kipas listrik yang 
digunakan memiliki ukuran bervariasi mulai dari yang terkecil hingga terbesar. Kipas listrik berukuran kecil biasanya digunakan oleh warung makan yang menjual sate maranggi, sementara kipas berukuran besar digunakan untuk rumah makan, misalnya, sekelas Rumah Makan Sate Maranggi milik Hj. Yetty. Sebuah rumah makan yang memiliki omzet hingga 2 kuintal daging perhari. Dengan demikian kipas yang digunakan harus memiliki ukuran yang cukup besar.

Alat pemanggang sate maranggi, sebagai peralatan pokok penjual sate maranggi, berbentuk persegi panjang dengan ukuran yang sesuai kapasitas sate yang akan dipanggang. Penjual sate keliling atau warung-warung kecil menggunakan alat panggang sate berukuran sekitar $15 \quad \mathrm{~cm} \quad \mathrm{x} \quad 40 \quad \mathrm{~cm}$. Sementara untuk warung atau rumah makan besar, ukuran yang dipergunakan dapat mencapai sekitar $20 \mathrm{~cm}$ x 1,5 m.

Arang turut menjadi bagian dalam proses pemanggangan sate maranggi. Jenis arang yang digunakan penjual biasanya berasal dari arang kayu. Jenis lain dari arang adalah arang tempurung kelapa, namun tidak dapat digunakan karena bentuknya yang pipih dan cepat membara. Hal ini akan berakibat sate yang dipanggang hanya akan matang pada bagian luarnya saja.

Hembusan angin dari kipas membuat bara hanya ada pada bagian dari atas, kiri, dan kanan. Untuk meratakan bara api digunakan sepotong besi berukuran $40-50 \mathrm{~cm}$ dengan pegangan pada bagian ujungnya. Cara kerja alat tersebut adalah dengan menusuk-nusuk dan membolak balikkan arang yang masih belum terbakar pada bagian bawahnya. Apabila menggunakan hihid, biasanya gagang hihid juga berfungsi sebagai alat untuk meratakan bara panggangan sate.

Pada rumah makan berskala besar, proses memanggang memerlukan arang dalam jumlah banyak. Peralatan yang digunakan untuk membawa arang ke dalam panggangan di antaranya sekop dan gayung. Kedua alat tersebut terbuat dari logam.

\section{- Peralatan Makan dan Minum}

Berbeda antara pedagang sate maranggi keliling dengan menetap. Pedagang sate maranggi keliling hanya menyediakan seperangkat piring dan gelas seadanya. Sangat jarang mereka menyediakan sendok dan garpu karena cara makan sate biasanya menggunakan tangan saja. Tidak lupa satu ember kecil berisi air yang digunakan untuk membersihkan peralatan makan minum yang telah dipakai pembeli. Satu teko alumunium berukuran kecil juga dibawa dan telah diisi dengan air teh tawar. Berbeda halnya dengan pedagang sate maranggi menetap, baik dalam bentuk warung ataupun rumah makan. Sejumlah besar peralatan makan minum akan disediakan.pedagang. Ada juga pedagang sate maranggi yang turut menyediakan menu tambahan (makan dan minum) selain menu utama, yaitu sate maranggi.

Ukuran dan bentuk peralatan makan minum (piring dan gelas) rata-rata sama, Perbedaannya hanya pada bahannya. Ratarata pedagang sate maranggi menyediakan peralatan makan dan minum yang terbuat dari kaca. Sebagian kecil khususnya pada peralatan makan (piring) saat ini ada juga yang menggunakan anyaman rotan. Hal ini tidak lebih dari sekedar strategi agar pembeli tidak memindahkan nasi terbungkus daun pisang ke dalam piring, yang berakibat pedagang harus mencuci piring agar dapat digunakan kembali. Piring dari anyaman rotan mengharuskan pembeli untuk menyantap hidangan tanpa harus membuang daun pisang.

\section{- Peralatan Meracik}

Tidak banyak peralatan meracik yang digunakan dalam pembuatan sate maranggi. Sate maranggi adalah sebagaimana sate secara umum, yaitu irisan atau potongan daging yang ditusuk dan dipanggang, tentunya memerlukan tusukan sate. Tusukan sate terbuat dari bilah bambu sepanjang $15-20 \mathrm{~cm}$ dengan 
diameter $1-2 \mathrm{~mm}$, dan makin meruncing pada salah satu ujungnya. Setengah dari panjang bilah bambu tersebut digunakan untuk irisan daging dan setengahnya lagi digunakan sebagai pegangan. Balastrang (baki) diperlukan untuk menaruh sate maranggi yang siap untuk dipanggang. Ukuran balastrang bermacam-macam sesuai dengan keperluan atau jumlah sate maranggi yang akan dipanggang.

Alat penggerus bahan juga diperlukan untuk menggerus bumbu balur sate maranggi sebelum memasuki tahap pemanggangan. Biasanya alat yang digunakan terbuat dari batu. Pisau juga diperlukan untuk meracik bahan-bahan semisal daun pisang, daun pepaya, cabe, dan lain-lain.

\section{b. Bahan dan Pengolahan}

Ada dua bagian besar yang diperlukan dalam pembuatan sate maranggi, yaitu bahan utama dan bahan bumbu. Bahan utama tidak lain adalah daging sedangkan bahan bumbu adalah bahan yang digunakan untuk menghasilkan rasa khas sate maranggi.

\section{- Pengolahan Bahan Utama (Daging) Sate Maranggi}

Daging sebagai bahan utama terdiri dari dua jenis, yaitu daging sapi dan daging domba. Dua jenis daging tersebut memiliki wilayah mayoritas penjual. Runutan perjalanan kuliner sate maranggi, menyatakan bahwa jenis daging yang dipilih pertama kali adalah daging sapi, sementara daging domba ada setelah beberapa tahun kuliner sate maranggi itu ada. Wilayah mayoritas penjual yang memilih daging sapi ada di wilayah Plered, sedangkan daging domba mayoritas di pilih oleh penjual di wilayah Pasawahan hingga Wanayasa. Dan, Wanayasa memang telah menyajikan daging doba sebagai bahan utama sate maranggi sejak dahulu.

Pemilihan dua jenis daging tersebut saat pertama dilakukan hanyalah berdasarkan atas cita rasa yang mengena di kedua wilayah tersebut. Kekinian, dengan adanya sedikit pengetahuan tentang dunia medis maka ditambahkanlah pertimbangan, khususnya daging domba yang dikatakan memiliki kadar kolesterol lebih tinggi, sehingga penjual di wilayah Plered lebih memilih daging sapi.

Daging sebagai bahan utama, dalam arti sebenarnya bukanlah daging dengan kandungan 100 persen. Dalam satu tusuk sate setidaknya ada satu atau dua potong lemak dari keseluruhan potongan yang rata-rata berjumlah empat iris. Dari pengamatan terhadap beberapa sentra sate maranggi, besar irisan daging rata-rata sama, kecuali pada pedagang keliling yang biasanya irisannya lebih kecil. Lain halnya dengan jeroan (lemak). Sate maranggi biasanya tidak menyertakan jeroan dalam setiap tusuknya. Berbeda dengan jenis sate lainnya yang terkadang menyertakan satu atau dua potong jeroan dalam setiap tusuknya.

Sebelum proses memasukan irisan daging ke tusukan, terlebih dahulu dilakukan proses pengempukan dan pencampuran bumbu. Dan, kedua proses inilah yang menjadi kekhasan sate maranggi. Pengempukan daging dilakukan dengan cara membungkus seluruh irisan daging dengan daun pepaya dan didiamkan selama kurang lebih tiga jam. Setelah itu, irisan daging yang telah empuk kemudian diberi bumbu penyedap yang terdiri dari gula merah dan garam. Prosesnya, gula merah dan garam dilumatkan hingga menyatu kemudian campur dan adukkan ke dalam irisan daging hingga merata. Selesai pemberian bumbu, dilakukanlah proses memasukkan irisan daging ke dalam tusukan satu persatu. Kumpulan tusuk sate tersebut ditaruh di dalam balastrang 'baskom' dan siap dipanggang.

\section{- Pengolahan nasi timbel}

Nasi timbel terdiri dari dua kata, yaitu : nasi" dan "timbel". Pengertian nasi adalah sama dengan definisi yang umum digunakan, yaitu hasil dari proses pemasakan padi. Sementara timbel adalah alat bungkus nasi yang menggunakan daun pisang. Walaupun sama dengan definisi 
secara umum, apabila dua kata kuliner tersebut digabung, yaitu nasi timbel, maka proses pemasakan nasi biasanya masih menggunakan cara tradisional yaitu dua kali proses pemasakan. Sementara cara modern hanya satu kali proses pemasakan. Jenis daun yang digunakan pada nasi timbel dari jenis daun pisang tertentu. Biasanya menggunakan daun pisang yang tidak mudah robek dan cepat kering. Kriteria tersebut biasanya akan mengarah pada daun pisang manggala. Saat ini, pohon pisang manggala sudah semakin sulit ditemukan sehingga penjual akan mencari jenis daun pisang lainnya untuk dipakai sebagai pembungkus pada nasi timbel.

\section{- Pengolahan Kuah}

Ada dua jenis kuah yang menjadi penambah rasa pada sate maranggi, yaitu kuah kacang dan kuah kecap. Dua jenis kuah tersebut biasa disajikan di warungwarung sate daerah Plered. Sementara sentra sate maranggi lainnya, yaitu Cibungur dan Wanayasa (termasuk Pasawahan) kebanyakan hanya menyajikan kuah kacang. Bahan dan pengolahan kuah kacang dan kecap berbeda antara satu sama lain.

\section{Kuah Kacang}

Bahan yang diperlukan untuk membuat kuah kacang terdiri dari: kacang tanah, cabe merah, bawang putih, kemiri, dan daun salam. Jumlah bahan tergantung dari banyaknya sate yang akan dijual. Proses pengolahan pertama adalah membuang kulit bawang putih untuk kemudian langsung ditumis bersama dengan seluruh bahan. Penumisan menggunakan media minyak goreng. Tidak perlu terlalu lama proses penumisan. Cukup ditandai dengan bau harum yang keluar saat penumisan, maka seluruh bahan tadi langsung diangkat dan dimasukan ke dalam cobek untuk digerus.

Cara penggerusan terdiri dari dua bagian. Bagian pertama adalah menggerus cabe merah, bawang putih, kemiri, dan daun salam. Seluruh bahan digerus sampai halus. Setelah halus, masuk ke tahap kedua, yaitu masukkan kacang tanah kemudian digerus namun tidak sampai lumat (halus). Setelah dirasa pas hasil gerusan, masukkan ke dalam wajan yang telah berisi sedikit minyak goreng. Goreng dan aduk-aduk kuah kecap tersebut hingga mendidih.

\section{Kuah Kecap}

Hampir sama dengan kuah kacang, kuah kecap juga memerlukan proses perebusan dalam cara pengolahannya, Adapun bahan yang diperlukan terdiri dari: bawang merah, tomat, Cabe rawit, bumbu penyedap, dan kecap. Jumlah seluruh bahan tergantung dari jumlah sate yang akan dijual. Proses pengolahan pertama dalam pembuatan kuah kecap adalah dengan mengupas bawang merah dan memotong kasar seluruh bahan, kecuali tomat dan kecap. Setelah itu, gerus seluruh bahan (kecuali tomat dan kecap) sampai benar-benar halus. Proses ketiga adalah memasukkan seluruh bahan ke dalam wajan yang telah berisi minyak goreng untuk ditumis. Aduk-aduk selama proses penumisan agar seluruh bahan tercampur rata. Setelah mengeluarkan bau harum, angkat dan jadilah kuah kecap.

\section{- Pengolahan Acar}

Sepertinya setiap penjual sate maranggi baik di berbagai sentra sate maranggi maupun pada pedagang keliling selalu menyediakan acar. Dan, memang demikian kenyataannya bahwa sajian acar seakan menjadi sajian pendamping yang wajib bagi setiap penjual sate maranggi. Belum diketahui memang, awal mula penyajian acar pada sate maranggi namun dapat diyakini bahwa unsur penyeimbang rasa antara rasa sate (apapun) yang terlapisi oleh lemak (basa) tentunya memberikan rasa gurih (terlalu) dan harus dilawan dengan rasa acar yang segar dan asam.

Kondisi kekinian, ada unsur medis yang menjadi penambah alasan mengapa acar selalu tersedia sebagai sajian pendamping dari sate maranggi. Walaupun demikian, pertimbangan medis dari 
kandungan kolesterol yang ada pada daging hanyalah sekilas pandangan dan wacana yang belum dapat dibenarkan secara akurat. Apalagi, dalam setiap penyajian sate maranggi, kerap dijumpai acar mentimun dan wortel yang sudah jelas menjadi penyeimbang dari rasa gurih lemak sekaligus kadar kolesterol baik pada daging sapi maupun daging domba.

Sajian pendamping tersebut memang kerap ada. Jawaban dari sang penjual biasanya memang terjadi begitu saja sementara mereka tidak mengerti betul fungsi medis dari sajian pendamping tersebut. Berdasarkan pengalaman penulis, mungkin ada sedikit persamaan dengan kuliner pada masyarakat Aceh yaitu sajian segelas air es yang ditambah parutan mentimun sebagai sajian pendamping dari kuliner gule kameng (Gulai Kambing).

Nuansa rasa segar yang memang tersaji pada acar diperoleh dari bahanbahan, yaitu: Bawang merah, Cabe rawit, Mentimun, Wortel, Gula pasir, Garam, dan Cuka makan.

Proses pengolahan untuk membuat acar cukup mudah. Pertama, Bawang merah dan wortel dikupas kulitnya. Setelah itu bersama mentimun, lalu dipotong kecilkecil dengan ukuran yang hampir sama. Tabur dan aduk gula pasir, garam, dan cuka ke dalam potongan-potongan bahan tersebut hingga merata.

\section{- Pengolahan Sambal Tomat}

Agak sedikit berbeda memang sajian pendamping yang satu ini karena hanya ada satu lokasi yang sengaja menyajikannya, yaitu warung sate maranggi $\mathrm{Hj}$. Yetty di Cibungur. Bahan yang digunakan mudah diperoleh dan mudah pula cara pembuatannya. Adapun bahan yang diperlukan adalah: Cabe rawit, Tomat merah, Garam, dan Gula putih.

Cabe rawit, garam, dan gula putih digerus kasar lalu tambahkan tomat merah yang telah diiris dan aduk hingga rata. Karena menggunakan bahan mentah, daya tahan sambal tomat tidak terlalu lama. Oleh karena itu, proses pembuatan dilakukan begitu ada pesanan.

\section{c. Penyajian}

Pola penyajian khas sate maranggi mengalami pergeseran antara bentukan awal dengan kondisi kekinian. Imbas dari pergeseran pola penyajian adalah dari jumlah sate maranggi yang dipanggang. Saat ini, jumlah sate yang dipanggang ratarata tergantung dari jumlah pesanan. Berbeda dengan era tahun 1970-an, sate yang dipanggang ditaruh di balastrang dalam jumlah secukupnya. Pembeli tinggal mengambil sate yang ditaruh dalam balastrang tersebut. Apabila dirasa sudah dingin, pembeli tinggal meminta penjual untuk menghangatkannya lagi. Setelah selesai bersantap, penjual menghitung jumlah tusuk sate yang ditaruh di dalam piring pembeli untuk kemudian dikalikan dengan harga pertusuknya.

Pergeseran yang terjadi bersifat masih parsial. Dengan kata lain, masih ada penjual sate maranggi yang menggunakan pola lama, yaitu menaruh dalam balastrang seperti yang masih dilakukan pada para penjual sate maranggi di Kampung Maranggi Plered. Namun, hal tersebut berlaku bagi pembeli yang sudah tahu mengenai tata cara penyajian khas sate maranggi. Bagi pembeli yang belum mengetahui tata cara tersebut, biasanya ia akan menanyakan harga per porsi. Dan, sang penjualpun akan menjawabnya dengan nominal yang telah disepakati bersama oleh sesama penjual sate di kampung maranggi Plered.

Perubahan pola penyajian yang sepenuhnya terjadi adalah di warung sate maranggi $\mathrm{Hj}$. Yetty. Pola penyajian sudah seperti rumah makan pada umumnya. Ada menu makanan yang sudah tersedia di setiap meja. Memang selain sate maranggi sebagai menu utama, ada beberapa menu tambahan dari beberapa counter hasil kerjasama dengan kerabat $\mathrm{Hj}$. Yetty.

Pola penyajian sate maranggi milik $\mathrm{Hj}$. Yetty agak sedikit berbeda dengan pola penyajian di Kampung Maranggi Plered. Dengan arsitektur unit penjualan sate maranggi yang khas, pembeli yang sudah mengenal pola penjualan akan mendatangi 
dan duduk di kursi yang tersedia. Penjual pun langsung bereaksi mengambil beberapa tusuk sate dan memanggangnya. Setelah matang, sate ditaruh dalam balastrang kemudian langsung diambil pembeli yang sebelumnya telah membuka satu timbel. Kuah kecap dan kacang sudah tersedia. Pembeli tinggal memilih di antara dua jenis kuah tersebut sebagai penambah rasa kuliner sate maranggi.

Tata cara makan adalah dengan mengambil satu tusuk sate kemudian mencelupkan ke dalam kuah. Tidak boleh mencelupkan sate lebih dari satu kali. Jadi, setelah mencelupkan ke dalam kuah, sate langsung ditaruh ke dalam nasi timbel dan dimakan. Apabila hendak dicampurkan dengan nasi, telah tersedia sendok pada kedua kuah tersebut. Pembeli tinggal mengambil beberapa sendok dan menuangkannya ke dalam nasi.

Sendok memang telah disediakan pada tiap-tiap lapak sate di Kampung Maranggi, namun kebiasaan memakan sate maranggi adalah dengan jari tangan. Secara bergantian, setelah satu suapan biasanya langsung mengambi satu tusuk sate dan menggigit satu atau dua iris daging. Bagi yang hendak menambah nasi, daun pisang bekas timbel sebelumnya akan dikeluarkan dari piring dan digantikan dengan timbel yang baru. Atau, dapat juga dilakukan dengan cara menumpuk timbel yang baru di atas daun pisang sisa timbel sebelumnya.

Bekas tusuk sate maranggi kemudian ditaruh di atas / samping daun timbel. Pembeli yang telah selesai bersantap kemudian menanyakan nominal yang harus dibayarkan. Penjual kemudian langsung mengambil tusuk sate bekas pakai, sambil melihat jumlah daun bekas timbel. Nominal ditentukan cara :

- Jumlah tusuk sate x harga (Rp. 1.500)

- Jumlah daun timbel x harga (Rp. 2.000) ${ }^{2}$

Terkadang ada juga pembeli yang hendak menyantap sate maranggi di rumah atau di tempat lain. Ia kemudian meminta

\footnotetext{
${ }^{2}$ Harga satuan yang tercatat pada tahun 2016
}

kepada penjual untuk membungkus sate maranggi. Jumlah sate tergantung permintaan pembeli. Namun demikian, jumlah yang biasa dipesan adalah per porsi yaitu 10 tusuk sate maranggi. Kuah sate bisa dicampur langsung ke dalam satu bungkus atau dapat juga dipisahkan dengan menggunakan kantong plastik kecil. Setelah sesampainya di rumah, biasanya mereka akan segera menyantap sate maranggi yang masih hangat. Apabila dingin atau dibiarkan seharian, menurut Pitasari akan mengalami penurunan mutu yang disebabkan oleh pertumbuhan mikroorganisme (bakteri dan kapang) sehingga menyebabkan timbulnya bau yang kurang enak (tengik), serta terbentuknya lendir, gas, warna, asam dan toksin (tt: 14).

\section{d. Kondisi dan Upaya Pelestarian Kuliner Sate Maranggi}

Menurut Mustika dalam penelitian tentang faktor yang mempengaruhi kebertahanan pedagang kuliner tradisional di Kabupaten Klungkung, setidaknya ditemukan 5 faktor, yaitu kemudahan memperoleh modal usaha, ketersediaan bahan baku, proses pengolahan bahan baku, proses pemasaran, dan pengaruh keberadaan pesaing (2013: 124). Poin 1 sampai dengan 4 khusus mengenai sate maranggi tidak mengalami kendala karena sate ini memang sudah memasyarakat utamanya di Kabupaten Purwakarta. Poin 5 tampaknya menjadi fokus utama untuk diberdayakan karena daya saing yang cukup gencar dari kuliner modern.

Saat ini kuliner sate maranggi dapat dikatakan sudah semakin berkembang. Hal tersebut dapat terlaksana karena ada upaya serius dari Pemerintah Daerah Kabupaten Purwakarta untuk mengangkat berbagai potensi budaya yang dapat meningkatkan taraf perekonomian masyarakat di Kabupaten Purwakarta. Langkah-langkah yang dilakukan secara khusus dibebankan kepada Instansi yang terkait dengan bidang industri, bidang perdagangan, juga bidang kebudayaan, dan bidang pariwisata Kabupaten Purwakarta. Instansi terkait 
tersebut kemudian berupaya melakukan pembinaan dan pengembangan kuliner sate maranggi agar lebih dikenal tidak saja oleh masyarakat Kabupaten Purwakarta tetapi juga di daerah lainnya. Salah satu upaya yang dilakukan adalah dengan mengadakan Festival Kuliner Sate Maranggi antarkecamatan. Kegiatan ini bermaksud untuk menggerakkan ekonomi rakyat, Festival Steak Maranggi, dan sebagainya. Festival Steak Maranggi dimaksudkan untuk menggerakkan anak muda mencintai makanan lokal. Bentuk steak diangkat untuk menyesuaikan kebiasaan anak muda makan. Oleh karenanya, festival tersebut merangkul peserta dari anak-anak muda di tingkat sekolah menengah atas (SMA) dan sekolah menengah kejuruan (SMK). Meski dinamakan festival, untuk menambah daya tarik telah disiapkan sejumlah hadiah bagi peserta yang membuat steak maranggi terbaik. Strategi yang dikembangkan oleh Pemda Kabupaten Purwakarta dapat dikatakan terinspirasi dari kepopuleran Kota Bandung. Di kota ini, menurut Nurwitasari (2015: 92-102) upaya serius dilakukan Pemkot Bandung untuk memberdayakan gastronomi di bidang makanan sebagai upaya memikat wisatawan.

Selain itu, sate maranggi juga diangkat melalui keberadaan Kampung Maranggi yang berdiri di daerah Situ Buleud, tempat berdirinya air mancur yang cukup fenomenal. Air mancur tersebut dinyalakan setiap malam Minggu pada sekitar pukul 19.30. Para pengunjung yang hendak menikmati keindahan air mancur tidak lupa untuk menyantap sate maranggi sebagai kuliner khas Kabupaten Purwakarta. Pedagang sate maranggi berada di area sekitar air mancur setiap malam Minggu mulai pukul 19.00 hingga pukul 23.00 WIB.

Upaya Bupati dalam
memberdayakan dan memperkenalkan sate maranggi secara luas menimbulkan banyak ide kreatif. Selain dua bentuk kegiatan tersebut di atas ide kreatif lainnya adalah pembuatan jingle dan tarian khusus sate maranggi. Aransemen yang bernada riang khas sunda dipadukan dengan tarian dengan mengenakan kostum budaya sunda sambil tidak lupa membawa hihid sebagai alat utama dalam proses pemanggangan sate maranggi. Lenggak-lenggok penari secara riang kerap menjadi atraksi menarik sambil diiringi gaya mengipas-ngipaskan hihid layaknya sedang memanggang sate maranggi.

Asal mula lokasi sate maranggi yang berada di Plered tidak akan diterlantarkan begitu saja. Malah menjadi prioritas utama dalam mempromosikan sate maranggi. Pertimbangannya adalah Plered merupakan cikal bakal keberadaan sate maranggi. Dari sejak dahulu hingga sekarang pedagang sate maranggi selalu ada utamanya di wilayah Stasiun Plered. Kondisi yang terkesan kumuh tersebut kemudian mendorong Pemda Kabupaten Purwakarta melakukan pembenahan dan memperindah wilayah pedagang sate maranggi dalam bentuk sentra sate maranggi di samping Stasiun Plered. Puluhan pedagang sate maranggi memenuhi setiap lapak yang memang disediakan secara gratis oleh Pemda Kabupaten Purwakarta.

Tidak hanya di dalam negeri, Promosi sate maranggi juga dilakukan di luar negeri. Salah satunya di Filipina pada tahun 2015 dalam ajang World Street Fod Congres. Di ajang tersebut, kuliner sate maranggi menempati counter yang cukup luas dan tertata apik. Banyak pengunjung yang tertarik dan ingin merasakan kelezatan sate maranggi.

Dalam ajang kegiatan pemerintahan, promosi sate maranggi bahkan menjadi salah satu menu santapan kenegaraan seperti yang dilakukan oleh Presiden RI tatkala menjamu para CEO dari Korea Selatan yang bergerak pada berbagai bidang, antara lain pabrik garmen, energi terbarukan, farmasi, dan produksi ban dalam acara Working Lunch dengan 20 perusahaan besar Korea Selatan di Athena Garden, Lotte Hotel, Seoul, Senin, 16 Mei 2016. 
Selain kegiatan atau acara yang berkenaan dengan upaya mengangkat nama kuliner sate maranggi di atas, beberapa peraturan daerah juga telah dibuat dalam kerangka memperkuat potensi dan nilai budaya yang menjadi landasan karakter dan taraf perekonomian masyarakat di Kabupaten Purwakarta. Sate maranggi menjadi sebuah peluang besar demi tercapainya tujuan tersebut karena dapat merangkum sisi ekonomi dan potensi budaya menjadi sebuah trend yag sangat lekat dengan kekayaan budaya Purwakarta.

\section{PENUTUP}

Makanan merupakan salah satu kebutuhan pokok manusia yang harus dipenuhi. Setelah manusia untuk pertama kalinya mengenal proses pemasakan dan penggunaan bumbu, manusia mulai mengembangkan variasi masakan sehingga tercipta menu masakan yang hingga kini tidak terhitung jumlahnya.

Menu dan citarasa masakan adalah dinamis, artinya tergantung dari minat dan kecintaan masyarakat terhadap menu masakan tersebut. Datangnya menu dan trend kuliner baru ke dalam sebuah kelompok menjadi sebuah ujian bagi kuliner yang sudah ada dan melekat di hati masyarakat. Sate maranggi yang memiliki citarasa khas dan dianggap mewakili citarasa umum yang dimiliki masyarakat luas, sebelum adanya upaya pelestarian oleh Pemda Kabupaten Purwakarta seakan berjalan di tempat. Sate maranggi kala itu menjadi sebuah kuliner yang hanya dikenal oleh intern masyarakat Kabupaten Purwakarta saja. Saat ini, kondisi tersebut sudah berubah 180 derajat. Upaya pelestarian yang gencar dilakukan oleh Pemda Kabupaten Purwakarta kini merubah wajah sate maranggi menjadi sebuah kuliner yang mampu bersaing dengan trend kuliner yang saat ini sedang booming.

Upaya positif yang dilakukan Pemda Kabupaten Purwakarta sudah seharusnya mendapatkan apresiasi dari kabupaten/kota lain dan ditanggapi dengan melakukan aksi serupa terhadap aset budayadi wilayahnya. Karena, dengan semakin banyaknya ikonikon budaya di tiap-tiap kabupaten/kota, maka, simbol dari keanekaragaman yang dibungkus dengan ke-tunggal ika-an yang menjadi ciri dari karakter kebangsaan Indonesia akan semakin terasa wujud dan aktivitasnya.

\section{DAFTAR SUMBER}

\section{Makalah, Laporan Penelitian, Skripsi, Tesis, dan Jurnal}

Hardjasaputra, A. Sobana. Sejarah Purwakarta, Purwakarta: Dinas Pariwisata. Pemkab Purwakarta. 2004

Mustika, Made Dwi Setyadhi ; Putu Desy Apriliani. "Analisis Faktor-faktor yang Mempengaruhi Kebertahanan Pedagang Kuliner tradisional di Kabupaten Klungkung", dalam Jurnal Ekonomi Kuantitatif Terapan Vol. 6 No. 2 Agustus 2013 hlm. 119 - 127.

Nurwitasari, Ayu. "Pengaruh Wisata Gastronomi Makanan Tradisional Sunda terhadap Keputusan Wisatawan Berkunjung ke Kota Bandung," dalam BARISTA Volume 2, Nomor 1 Juli 2015 hlm. 92 - 102.

Pitasari, Ulil Hikmah; Thomas Gozali; Yudi Garnida. "Pendugaan Umur Simpan Sate Maranggi Dengan Metoda Aslt (Accelerated Shelf Life Testing) Berdasarkan Pendekatan Arrhenius", Makalah pada Jurusan Teknologi Pangan Fakultas Teknik Universitas Pasundan Bandung, tt hlm. 1 - 30.

Tim Penyusun Kamus Pusat Bahasa, Kamus Bahasa Indonesia, Jakarta: Pusat Bahasa, 2008

Tim Teknis Direktorat Jenderal Kebudayaan, Petunjuk Teknis Penggunaan Aplikasi Sistem Data Pokok Kebudayaan, Jakarta: Direktorat Jenderal Kebudayaan, 2015.

Wurianto, Arif Budi. Aspek Budaya Pada Tradisi Kuliner Tradisional Di Kota Malang Sebagai Identitas Sosial Budaya (Sebuah Tinjauan Folklore), "Laporan Penelitian", Malang: Lembaga Penelitian Universitas Muhammadiyah Malang, 2008 


\section{Internet}

travel.kompas.com, "Jangan Kaget, Inilah Sebenarnya Asal Usul Sate Maranggi", dalam http://travel. kompas.com/read/2016/05/20/20020072

7/Jangan.Kaget.Inilah.Sebenarnya.Asal. Usul.Sate.Maranggi, Jumat, $20 \mathrm{Mei}$ 2016 